\title{
Factors Affecting Purchase Decision for Indian Two Wheelers in Sri Lankan Market
}

\author{
R. A. S. Weerasiri ${ }^{1}$ and A. S. M. G. Mendis ${ }^{2}$ \\ ${ }^{1,2}$ Department of Marketing Management, Faculty of Commerce and Management, \\ University of Kelaniya, Sri Lanka \\ ${ }^{1}$ sudathweerasiri@hotmail.com
}

\begin{abstract}
Within the past decade two wheeler usage indicates a rapid growth in Sri Lankan market. Among the two wheeler population, Indian two wheeler brads representing a huge portion.. In this research study researcher put effort to find out what are the factors effect on decisions of consumers on Indian two wheelers as a novel research. Main purpose of this study was to identify why Indian two wheeler brands becoming more popular and which factors effect on the purchasing decision and open up the gateway to study on this area among this study. Researcher's previous working experience at Automotive Industry was lead to conduct the study. Data were collected from four districts representing the Sri Lankan population using questionnaire. According to the literature review researcher employed six variables namely Price, Technology and Design, Product Awareness, Spare Parts Availability, After Sales Services and Economic Conditions. Data was gathered from two wheeler users and non-users who are having ether two wheeler or willing to have a two wheeler. The findings also revealed several implications for marketers to better segmentation and targeting in the automobile industry especially on two wheeler sales. Further contribution of the demographic factors such as age, gender, income level, education level how far impacted on the purchasing decisions of the two wheelers and those are helpful to marketing managers to develop their strategies. Ultimately the study provides important insides how the variables are impact on purchasing decisions towards the Indian two wheelers at the Sri Lankan market.
\end{abstract}

Keywords: Purchasing Intension, Two Wheelers, Indian Brands

\section{Introduction}

With the globalization of the world, people are trying to moving a place to another place using easiest method. Because people are busy than past decade. People faced difficulties in managing time for their day to day activities, especially on moving within the places. Also In the recent decade, Sri Lankan transportation infrastructures being rapidly increased, example is a person can travel to Colombo main city from Galle town within two hours $(117 \mathrm{~km})$. But the facts road traffic and need for personalized traveling need, leads to think about the different traveling methods. Then peoples focus on whether they use public transportation method (buses, staff transportation services and trains) or their own method. Most of people think to use their own methods, but the limitations such as high price of vehicles, traffic at the urban area, high price on fuel will against to the decision of purchasing a vehicle. If we are analyzing a "Road Flow Theory" to Colombo metropolitan area, it suggested not using personal vehicle in that area, because of the high traffic. 
So in such situation, traveler has to consider and he should have an option to implement. World's automotive industry brings an easiest and affordable solution called two wheelers to avoid such problems. In the early decades two wheelers design varies greatly to suit a range of different purposes, such as long distance travel, navigating urban traffic, cruising, sport, racing and off-road riding. But the Sri Lankan context it is totally different, because Sri Lankan two wheeler customers think two wheelers are the economical method of transportation and user friendly method. Most of customers prefer some two wheeler brands due to above reason.

Two wheelers are one of the most affordable forms of motorized transport and, for most of the world's population; they are the most familiar type of motor vehicle. After introduce the motor bike in 1884, different kind of eras of two wheelers, country origins and different companies can be seen. But in the modern era Japanese two wheelers are dominating the entire global market. But in the south Asian region Indian Brand two wheelers are the threat for Japanese two wheeler market. These facts highly affect to Sri Lanka as well.

India's automobile market has grown steadily over the last decade, Road Motor Vehicle department of Sri Lanka (RMV) statistics shows the Indian branded two wheelers have considerable amount of registration in Sri Lanka including major five Indian Two wheeler players.

Research revealed the customer perception toward the Indian Two wheelers (Motor Bikes) in the Sri Lankan Automotive Market. Two wheelers are the one of most important part of the Automotive Market in Sri Lanka. In recent years registration of Indian two wheelers is increasing in our country. RMV statistics shows that 2,642,438 two wheelers have been registered at the end of July 2013. Further it shows 192,284 two wheelers have been registered in 2012 year. According to the statistic, Bajaj, Honda, Yamaha, TVS, Mahindra are the key players in India as well as Sri Lankan market. Most of Sri Lankan two wheeler customers are prefer to buy these brands.

When talking about the Two Wheeler consumers, most of the consumers are in the 20 to 37 years of age, using the motor bikes. In Sri Lanka, every male's first aim is to buy a brand new two wheeler. It can be a Japanese one. But the legal restrictions are the key benefit to Indian brand to gain advantage from Sri Lankan market. Such as, duties and taxes when importing.

Indian Two wheelers are the most selling bikes when compared to other origins such as Japan, China and US bikes. 53\% of registered two wheelers represent the total vehicles in Sri Lanka and more than $65 \%$ of bikes represent the Indian motor bikes belong to above mentioned two wheeler brands. 


\section{Literature Review}

Financing and competition was create the affordability to the motor bike to the consumers then create the demand, ultimately sales figures were increased (Chintan Shah, 2011). In an analyst meet of TVS Motors in mid-2002, the company said that, as much as $40 \%$ of its motorcycle sales are financed. It will be safe to assume higher numbers for the industry as well. (Chintan Shah, 2011). According to the Michel Porter, 5 forces analysis will illustrate the industry condition of the two wheeler market. Threats of substitutes are in 150-250cc segment there is less risk of substitutes. However in lower segment $(90-150 \mathrm{cc})$ penetration could be seen towards non gear scooter. Bargaining Power of suppliers is less as quantity supplied is huge and prices of raw materials has come down. Basic raw material required are steel and rubber. Bargaining power of buyers Customers get a healthy choice, Depends on taste and brand loyalty of the customer. Supply-demand mismatch in the industry (supply is greater). Rivalry among existing firms are having 6 major companies in market, competition is high, compete each other in terms of better model, specifications and technology. Threat of new entrants are very high, Well established players are already existing (Abhinav Yadav, 2012).

Also SWOT analysis will give a clear understanding on the industry. Strength are easy availability of spare parts, cost of parts is low, has a high brand loyalty amongst the customers, Innovation in fuel efficient bikes in 150cc segments, mergers from international brands, exports of bikes is increasing. Weaknesses are, Hero is not getting the technical expertise from Honda after the merger, similar type of models with same specification; capacity utilization is low, skilled labor. Opportunities are increase in disposal income, credit financing by banks is increasing, increase in sale of sports bike segment. Threats are increase in fuel prices, inflation, economic slowdown (Abhinav Yadav, 2012).

India is the second largest producer of two-wheelers in the world. Indian two wheeler market has a size of over Rs100, 000 million (Mohomad Salman, Rajeev Vasudewan, 2012). In the rural areas, consumers have come to prefer sturdier bikes to withstand the bad road conditions. (Chintan Shah, 2011). Scooters and mopeds are rapidly losing their place in the market to the more fuel-efficient, stylish and sturdy motorcycles. The Euro emission norms effective from April 2000 led to the existing players in the two- stroke segment to install catalytic converters. 4-stroke motorcycles are now replacing all the new models. Excise duty on motorcycles has been reduced from $32 \%$ to $24 \%$, resulting in price reduction, which has aided in propelling the demand for motorcycles. More than 40 per cent of the motorcycle demand flowing from the rural sector (Chintan Shah, 2011). 
Vehicle imports to Sri Lanka continued to be dominated by India accounting $43 \%$ of total imported value and $72 \%$ of total imported quantity of vehicles and parts, according to an analysis done by the Ceylon Chamber of Commerce; Japan is the second largest supplier of vehicles and parts to Sri Lanka accounting $38 \%$ in terms of value and $20 \%$ in terms of quantity as per the analysis done by the Chamber on vehicle imports into Sri Lanka, made during the period of 2005 to 2013.The expenditure on vehicles and parts imports recorded a decline of $17 \%$ in 2013 compared to 2012 (Financial Times, April 28, 2014). RMV statistics show that high percentage of selling two wheelers among above few brands compared to the Japanese two wheelers. Bajaj is the no. 01 selling bike in Sri Lanka, it has 890,017 of bikes and TVS, Hero Honda, Hero Moto comp, and Honda (India) and Yamaha (India) respectively has 236289, 291065, 22483, 39092 and 23943 in recent years. But the Honda Japan, Yamaha Japan and SUZUKI has bikes respectively 622956, 207787 and 62984 with the old registrations. (Department of Motor Traffic Sri Lanka - Vehicles Registration in Sri Lanka RMV Statistics 2013 December)

\section{Objectives of the Study}

Under this research study, following objectives have been established.

\subsection{Main Objective}

The main objective of this study is to find out the reasons behind for demanding Indian two wheelers in Sri Lankan market

\subsection{Specific Objectives}

- To find out most customer preferable Indian motor bike brands in Sri Lankan market

- To find out considerable features highlighting among the Indian two wheelers

- To find out potential growth of the Indian two wheeler for Sri Lankan market

\section{Hypotheses of the Study}

i. $\quad \mathbf{H}_{1}$ : There is a relationship between Price and the consumer purchase decision towards to the Indian two wheelers

ii. $\quad \mathbf{H}_{2}$ : There is a relationship between Technology \& Design and the consumer purchase decision toward to the Indian two wheelers

iii. $\quad \mathbf{H}_{3}$ : There is a relationship between Product (Brand) Awareness and consumer purchase decision towards to the Indian two wheelers

iv. $\quad H_{4}$ : There is a relationship between Spare Parts availability and the consumer purchase decision towards to the Indian two wheelers 
v. $\quad \mathbf{H}_{5}$ : There is a relationship between after sales services and the consumer purchase decision towards to the Indian two wheelers

vi. $\quad \mathbf{H}_{6}$ : There is a relationship between Economic Purposes and the consumer purchase decision towards to the Indian two wheelers

\section{Methodology}

Under this research study researcher used to employ quantitative techniques in data collection with the priority of quantitative techniques. It is implemented using the questionnaire survey as the main data collection instrument of this research study. It was help to examine and explain the relationships that researcher tested via this research study in a clear manner. Researcher collected data via the questionnaire survey. The sample was cover the main four districts (Kaluthara, Colombo, Gampaha and Galle) using 200 respondents. Under this research questionnaire survey implement face to face discussion with filling the questionnaire using open ended question to get better understanding of respondents, likert scale used to get the true feeling of the respondent with strongly disagree to strongly agree and use direct questions. Use already collected secondary data for other purposes from road motor vehicle department (RMV statistics), automotive organization and industry publications, auto magazines, data via internet, paper articles and experience and data of previous research done for TVS Lanka ltd. These secondary data were help to run and plan the current research study. Primary data collection were done through the survey questionnaires from the two wheeler users (respondents). Qualitative data were used to describe a type of information that can be counted or expressed numerically. It was use to get better outcome for the study. Likert scale questions data were analyzed by coding different values for each response. Central tendency analysis has been employed to test the hypothesis, based on the result. Quantitative data were analyzed using the MS Excel and SPSS software.

\section{Findings of the Study}

\subsection{Consumer Preferences and Buying Decision}

Analysis \& the discussion of gathered data $\&$ the researcher has used both descriptive and inferential statistics in the form of frequencies, central tendency measurements and as well as Pearson Correlation analysis.

A significant portion of the sample was use motor bike for home use and their leisure activities (120 respondents $(60 \%))$. And most of them were daily use the motor bike (158 respondents (79\%). Respondents were spend or willing to spend Rs. 100000 250000 amount for motor bike (179 respondents $(89.5 \%)$ ), and most of them were prefer to having a Brand new motor bike (141 respondents $(70.5 \%)$ ) and still they prefer to use a motor bike with the engine capacity range between $(91 \mathrm{cc}-199 \mathrm{cc})$. 
When talking about the brand preference Bajaj becoming no.1 and respectively Honda India, Yamaha India, Hero and TVS brands become the ranking No. 02 to No.05.

Meanwhile the consumers in Sri Lankan market are prefer fuel consumption level between $41 \mathrm{Kmpl}-90 \mathrm{Kmpl}$ (163 respondents $(81.5 \%)$ ) also consumers become aware with the motor bike via above the line promotional campaign (93 respondents $(46.5 \%)$ ) like TV, Radio and Newspapers while 70 respondent were aware and influenced through the others recommendation. According to the study consumers highly considered the prices and price related information when purchasing a Indian Motor bike, also consumers highly consider the factors respectively price, technology and design, economic condition, product related awareness, after sales services and finally the spare parts availability base on the research study. According to the correlation analysis it was revealed that there is a significant relationships between each independent variable and consumer buying intension towards to the Indian two wheelers. According to the study consumers highly consider the prices and price related information when purchasing a Indian two wheelers, also consumers highly consider the factors like price, technology and design, economic condition, product related awareness, after sales services and the spare parts availability base on the research study.

\section{Table 01: Brand Preference of the Indian Two Wheeler Users}

\begin{tabular}{|c|c|c|c|c|c|c|c|c|c|c|c|}
\hline \multirow{2}{*}{} & \multicolumn{2}{|c|}{ Bajaj } & \multicolumn{2}{|c|}{ Hero } & \multicolumn{2}{c|}{ TVS } & \multicolumn{2}{c|}{ Honda } & \multicolumn{2}{c|}{ Yamaha } & \multirow{2}{*}{ Total } \\
\cline { 2 - 12 } & f & $\%$ & f & $\%$ & f & $\%$ & f & $\%$ & f & $\%$ & \% \\
\hline 1 & 78 & $39 \%$ & 29 & $14.5 \%$ & 19 & $9.5 \%$ & 46 & $23 \%$ & 28 & $14 \%$ & $\mathbf{2 0 0}$ \\
\hline 2 & 44 & $22 \%$ & 14 & $7 \%$ & 14 & $7 \%$ & 94 & $47 \%$ & 34 & $17 \%$ & $\mathbf{2 0 0}$ \\
\hline 3 & 52 & $26 \%$ & 23 & $11.5 \%$ & 16 & $8 \%$ & 38 & $19 \%$ & 71 & $35.5 \%$ & $\mathbf{2 0 0}$ \\
\hline 4 & 24 & $12 \%$ & 59 & $29.5 \%$ & 64 & $32 \%$ & 22 & $11 \%$ & 32 & $16 \%$ & $\mathbf{2 0 0}$ \\
\hline 5 & 2 & $1 \%$ & 75 & $37.5 \%$ & 87 & $43.5 \%$ & 0 & $0 \%$ & 35 & $17.5 \%$ & $\mathbf{2 0 0}$ \\
\hline Total & 200 & & 200 & & 200 & & 200 & & 200 & & $\mathbf{2 0 0}$ \\
\hline
\end{tabular}

(Survey Data, 2014)

And still most famous brand is Bajaj Pulser and Yamaha FZ and Bajaj Discover become No. 02 position.

Researcher analyzed the independent variable - "Price" variable became most important variable among the other variables, when analyzing the independent variable price variable became most important variable, According to the survey finding current price level for Indian two wheeler users, 127 respondents $(63.5 \%)$ were easily afforded to the price level for their two wheeler. Also 32 respondents $(16 \%)$ were having neutral idea regarding the statement. Meanwhile 41 respondents $(20.1 \%)$ had couldn't easily afforded to the prices when purchasing their two wheeler. Further researcher try to 
identify whether the respondent were aware of the current competitive prices offered by each two wheeler selling companies. According to the research findings 86 respondents $(43 \%)$ were aware about the level of prices by different companies and 47 respondents (18.5\%) were having neutral idea regarding the prices. Also 69 respondents $(34.5 \%)$ were not aware of the current market prices offered by the companies. After that researcher analyze whether the low and competitive prices for Indian two wheelers were influence to selecting the two wheeler, according to the survey findings 131 respondents $(65.5 \%)$ were highly influenced via the low prices of the Indian two wheeler, further 41 respondents $(20.1 \%)$ were having neutral idea. Meanwhile 28 respondents were not influenced via low prices.

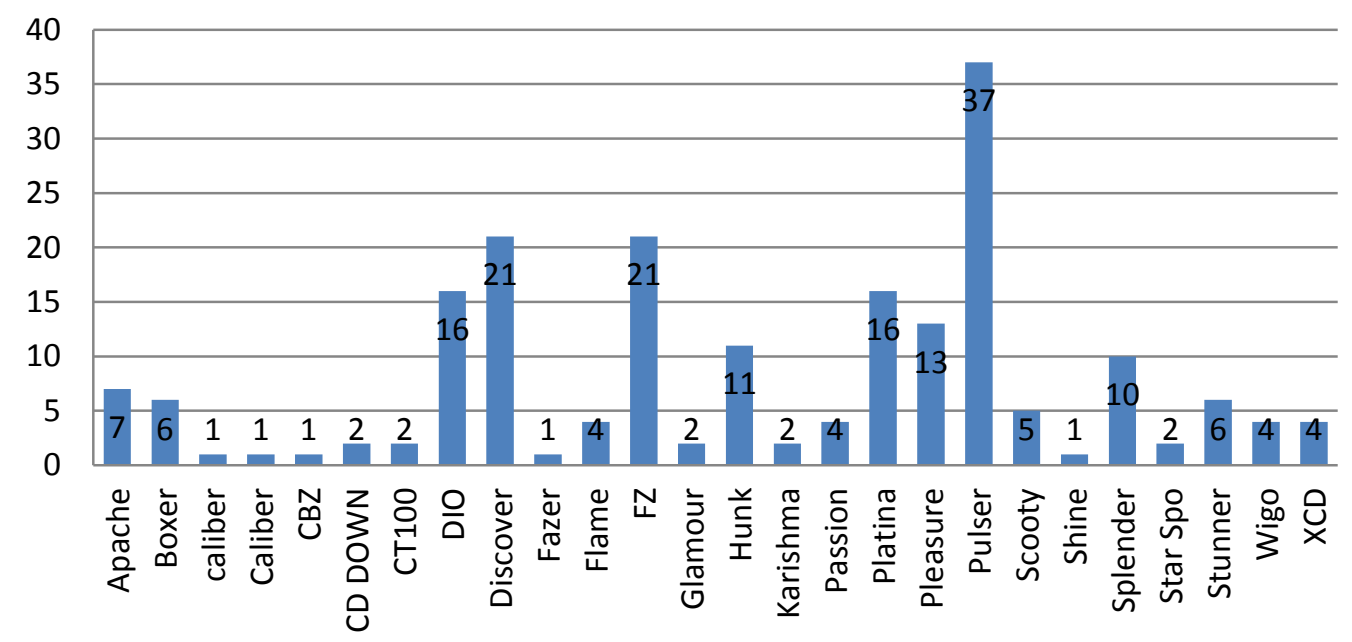

Figure 01: Model preference of the Respondents (Total 200) (Survey Data, 2014)

Also analyzed "Technology" variable for consumer buying intension and try to find out whether the respondent were focus more attention when purchasing a Indian two wheeler, according to the survey finding, 144 respondents (72\%) were highly influenced via the innovative technology that Indian two wheeler companies offering to the Sri Lankan market. Next respondents were asked whether the attractive color combinations and sticker designs were able to become the influenced factor when selecting a two wheeler. According to the findings 130 respondents (65\%) were highly influenced via stickers, colors and designs and 37 respondents having a neutral mind. Meanwhile 33 respondents $(16.5 \%)$ were not influenced via the attractive designs. Further researcher need to identify whether how far added accessories may lead the consumer buying intension towards Indian two wheeler at Sri Lankan market. According to the survey findings 88 respondents $(44 \%)$ were highly prefer to having a two wheeler with two wheeler accessories (added features) and 60 respondents (30\%) were agreed with the statement. While 24 respondents, 28 respondents $(14 \%)$ were not influenced via the added accessories. 
Next, researcher analyzed the "Product awareness" factor for Indian two wheelers, respondent were highly aware the two wheeler brands in Sri Lankan market, 165 respondent $(82.5 \%)$ were aware the brands. Again researcher try to identify whether the wide range of two wheeler availability were help to get a better preference among for their buying intension. 158 respondents were help to take a better decision via the wide range of model availability. Further researcher try to identify whether the attractiveness ant information of the advertisement by the two wheeler companies in Sri Lankan market, how far grab the attention from the two wheeler users. According to the survey findings 95 respondents $(47.5 \%)$ were influenced via attractive advertisements and its information, also 47 respondents $(23.5 \%)$ were having neutral idea, meanwhile 58 respondents $(29 \%)$ were not influenced via the advertisements. After that researcher try to identify whether the respondent were aware the full two wheeler model specification of their two wheeler. According to the findings 87 respondents $(43.5 \%)$ were aware the specification, while 55 respondents $(27.5 \%)$ were having a neutral idea, also 69 respondents (34.5\%) were doesn't aware the model specification of their two wheeler.

Next, researcher analyzed "Spare Parts Availability" variable, respondents did not aware the spare parts and its brands of their two wheeler (154 respondents $(77 \%)$ and 77 respondents $(38.5 \%)$ were disagreed with the statement. 30 respondents $(15 \%)$ were not able to give a clear idea.

After that researcher's investigation was, how far low prices of spare parts were influence to make the purchase decision. When purchasing recondition vehicle spare parts are the most considering factor to make purchasing decision. But survey findings prove that above fact not remain constant when purchasing a two wheeler according to the findings 164 respondents $(82 \%)$ were not consider the low price when purchasing a motor bike. And 25 respondents were not able to provide a clear answer and 11 respondents were considering the low price of spare parts when purchasing an Indian two wheeler. Further researcher need to investigate spare parts availability has done a major impact to purchase Indian two wheelers, survey findings same as the above measurement variable and big portion of sample population were strongly disagreed, (159 respondents $(79.5 \%)$ ) were not consider the spares availability. Meanwhile 28 respondents $(24 \%)$ were not able to provide a clear answer. And 13 respondents were considering the spares availability fact when purchasing an Indian two wheeler.

Researcher's next analyzed to identify how far "After Sales Services" made a massive impact to make a purchase decision to purchase an Indian two wheeler. Research finding illustrate that 123 respondents $(61.5 \%)$ were highly aware and 43 respondents $(21.5 \%)$ were not able to provide a clear answer whether they aware or not, and 34 respondents not aware the free services offered by the companies. After researcher asked how far warrantee option may lead to the influence to make a purchase decision. According to the findings 119 respondents (34.5\%) were highly focus on warrantees and 39 
respondents (19.5\%) were having neutral idea, 44 respondents were not focused the warrantee options. Next statement researcher include to measure how far free registration and easy documentation handling were able to make a purchase decision on Indian two wheeler. Findings shows 110 respondents $(55 \%)$ were agreed with the statement and 48 respondents $(24 \%)$ were not able to provide a clear idea. Meanwhile 23 respondents were disagreed with the statement and 37 respondents were not considering the fact.

"Economic Condition" variable related indicators are the influence factor for buying intension for an Indian two wheeler. Most of respondents were talk about the low fuel consumption and they were influenced, in recent years Sri Lankan two wheeler users were tend to purchase a Indian two wheeler, they always highlighting fuel consumption is far better than the Japanese two wheeler. Research findings also proving that the fact 134 respondents $(42.5 \%)$ were influenced via the low fuel consumption of the Indian two wheeler. also 40 respondents $(20 \%)$ were not able to provide a clear idea. And 26 respondents were not consider low fuel consumption and rejected the fact.

After the analysis of independent variable researcher analysis the dependent variable and its measurement indicators, whether they recommend the brand to someone else, whether they buy the same brand in the future and ultimately were they satisfy with their two wheeler. Finding figures shows respondents were asked whether they buy a same brand name (not model name) in next time when they are going to purchase a two wheeler as a Consumer Buying Intension Indicator, according to the findings, respondents were highly prefer to having a new model from the same brand name (151 respondents $(75.5 \%)$ ) and 30 respondent were not able to give a clear idea. Meanwhile 19 respondents were not willing to purchase again the same brand. After that researcher clarified whether they recommend the same brand to someone else, finding figures shows that respondents were strongly like to recommend their Indian two wheeler to someone else (82 respondents $(41 \%))$ and 68 respondents were willing to recommend the brand to others (68 respondents $(34 \%)$ ). Meanwhile 29 respondents $(14.5 \%)$ were not give clear answer, and 21 respondents were not recommend the brand to others. When considering the overall satisfaction level of the Indian two wheeler users at the Sri Lankan market, 91 respondents $(45.1 \%)$ were highly satisfied with the brands, models, prices, maintenances, after sales services, technologies and other features and functions that their two wheeler were having. Further 56 respondents $(28 \%)$ were agree with the statement and 32 respondents $(16 \%)$ having a neutral idea, also 12 respondents were disagreed and 8 respondents were not satisfactory with their two wheeler.

After analyzing the Consumer Buying Intension Dependent Variable, the correlation figures shows the hypothetical relationships as follows. 
Table 02: Results of the Hypotheses Testing

\begin{tabular}{|c|c|c|c|}
\hline & Hypotheses & Correlation Analysis & Result \\
\hline 1 & $\begin{array}{l}\text { There is a relationship } \\
\text { between Price and the } \\
\text { consumer preference towards } \\
\text { to the Indian two wheelers }\end{array}$ & $\begin{array}{l}\text { Coefficient correlation } \\
=0.944 * * \\
\text { Significance as } \\
p=0.000\end{array}$ & $\begin{array}{l}\text { A strong uphill (positive) } \\
\text { linear relationship }\end{array}$ \\
\hline 2 & $\begin{array}{l}\text { There is a relationship } \\
\text { between Technology \& } \\
\text { Design and the consumer } \\
\text { preference toward to the } \\
\text { Indian two wheelers }\end{array}$ & $\begin{array}{l}\text { Coefficient correlation } \\
=0.973^{* *} \\
\text { Significance as } \\
p=0.000\end{array}$ & $\begin{array}{l}\text { A strong uphill (positive) } \\
\text { linear relationship }\end{array}$ \\
\hline 3 & $\begin{array}{l}\text { There is a relationship } \\
\text { between Product (Brand) } \\
\text { Awareness and consumer } \\
\text { preference towards to the } \\
\text { Indian two wheelers }\end{array}$ & $\begin{array}{l}\text { Coefficient correlation } \\
=0.966^{* *} \\
\text { Significance as } \\
p=0.000\end{array}$ & $\begin{array}{l}\text { A strong uphill (positive) } \\
\text { linear relationship }\end{array}$ \\
\hline 4 & $\begin{array}{l}\text { There is a relationship } \\
\text { between Spare Parts } \\
\text { availability and the consumer } \\
\text { preference towards to the } \\
\text { Indian two wheelers }\end{array}$ & $\begin{array}{l}\text { Coefficient correlation } \\
=0.691 * * \\
\text { Significance as } \\
p=0.000\end{array}$ & $\begin{array}{l}\text { A moderate uphill } \\
\text { (positive) relationship }\end{array}$ \\
\hline 5 & $\begin{array}{l}\text { There is a relationship } \\
\text { between after sales services } \\
\text { and the consumer preference } \\
\text { towards to the Indian two } \\
\text { wheelers }\end{array}$ & $\begin{array}{l}\text { Coefficient correlation } \\
=0.944 * * \\
\text { Significance as } \\
p=0.000\end{array}$ & $\begin{array}{l}\text { A strong uphill (positive) } \\
\text { linear relationship }\end{array}$ \\
\hline 6 & $\begin{array}{l}\text { There is a relationship } \\
\text { between Economic Purposes } \\
\text { and the consumer preference } \\
\text { towards to the Indian two } \\
\text { wheelers }\end{array}$ & $\begin{array}{l}\text { Coefficient correlation } \\
=0.957 * * \\
\text { Significance as } \\
p=0.000\end{array}$ & $\begin{array}{l}\text { A strong uphill (positive) } \\
\text { linear relationship }\end{array}$ \\
\hline
\end{tabular}

(Analyzed Data, 2015)

\section{Conclusion}

If sale is heart of the business then marketing is brain of the business. Every organization operates with a view of making profit. Indian two wheeler companies in Sri Lankan market are also earning profits by selling their products to its customers. But it is not an easy task since consumer in this market confronts more various kinds of products available in the market. Highly competitive situation in the market causes marketers to work extensively to gain the customers' satisfaction and market share. 
All the companies in automotive industry spend a huge amount of money on different kinds of marketing strategies to increase their customer base while clearly identifying the customer inside regarding the consumer purchasing intension. As per the research the price, technology, awareness regarding the product, spare parts availability, after sales services and economic condition has a significant relationship with the buying decision of the two wheeler users. So the above factors have a greater influence on increasing the market share of the company.

According to the research outcome five variables (price, technology, awareness regarding the product, after sales services and economic condition) having are the most influence element of consumer purchase decision of Indian two wheeler, \& meanwhile spare parts availability is the less influence factor when making a purchasing decision.

Pricing strategies should adjusted with the economic situation, should strangest the after sales services to create the brand referrals, newest technologies and style should be educate among the market and highly promoted, resources of the organization and it should be well managed to derive the optimum results. So the marketing strategies should be developed with careful planning and consideration.

The research is the newest study and has implications on variables for Consumer Buying Intension towards Indian two wheeler. The framework provides new insights into the understanding of the impact of price, technology, awareness regarding the product, spare parts availability, after sales services and economic condition on consumer purchase decision. The results also have implications for professionals, because it helps two wheeler marketers in Sri Lankan market to better understand how the two wheeler users consider above factors attached with two wheeler brands when making their purchase decisions. further this study bring the fact what are the most famous Indian two wheeler brands, what are the famous model, what are the most famous engine capacities, what kind of purposes to use, how they were aware and influence to the brands among the Sri Lankan two wheeler users.

Through hypotheses testing the research also revealed that each measurement variable in the study how far impacted with the consumer buying intension and those variables have strong \& significant degree of relationships. So the two wheeler marketers can adapt this knowledge to their marketing plan and activities to satisfy customers and provide the offerings based on the factual consumers' needs. As the findings indicated that five out of six variable highly influential on consumer purchase decision so based on that organizations can carefully plan to allocate budget over different marketing activities, giving preference \& priority to the more influencing those elements on purchase decision \& consequently the companies can better plan out their marketing activities in the future. 
The study had limitations such as time limitations, financial limitations \& lack of secondary information available on two wheeler industry in Sri Lanka. Also the target population was limited to small number of respondents (200). So, future researches may use random sample with larger population to increase the reliability of the result. This is a newest research and most of considerable buying intension factors may missed by the researcher. But the above indicators are the massive impacted factors (six variables) when purchasing a two wheeler (research finding proved). Further newest study researcher can identify the above independent variable and they can implement their study. Example is how far Price become impact to buying intension toward Indian two wheeler in Sri Lankan market, further other five independent variables also implemented at the same way.

This research study is a broad study but it is not a complete study; this research study will open the door to the researchers who will like to conduct their researches in consumer purchasing intension at automobile industry. Because there are few researches studies were done before in the past in buying intension for automobiles.

\section{References}

Abhinav Yadav, (2012) Industry analysis on two wheeler industry, final year undergraduate, Osmania University

Allegro Capital Advisors Pvt Ltd (2011 December), India Automobiles - Two Wheelers Arun Aravindan, (2012) Indian Two Wheeler Market Analysis, Autobei Consulting Group

Asifur Rahman, Sadman Prodhan, The Marketing Strategy of Two Wheeler Products in Bangladesh, (MBA Dissertation) University of Dhaka

Chanthima Plabdaeng (2010) University Sains Malaysia - Gender Influence on Purchase Intention. The Case Study of Thailand

Chintan Shah, (2011) Two Wheeler industry in India, Final year Research, Undergraduate of University of Mumbai

KPMG India, (2012 December), The Indian Automotive Industry Evolving Dynamics (pg.no 7 $-12,17-25,29)$

Mohomad salman, Rajeev Vasudewan, (2012 May) “Two wheeler industry in India” Research Paper

Murali Karishma, Study of Consumer Behavior Regarding Two Wheeler (Automobile Industry), University of Chennai.

P.Tamilmozhi, Ph.d. Research Scholar in Commerce, consumers' behaviour towards Two Wheeler motor bikes, Manonmaniam Sundaranar, University, Tirunelveli.

Sunil D Tiwari, (2008 - 2010) Comparative Study on Consumer Buying Behavior of Hero Honda and Pulsar, ICFAI National College 
Surjit Arora, (2013 January) Automobiles - Two Wheelers - Growth likely to slow down

Tarang P Patil, (2007 March), a Study on Consumer Buying Behavior at Time to Purchase Hero Honda Bike, the Surat People's. Bank College of Business Administration - Udha, March 2007

Syed Saad Hussain Shah, Jabran Aziz, Ahsan, the Impact of Brands on Consumer Purchase Intentions, Iqra University 